\section{Production of $\mathrm{NO}_{2}$ from Photolysis of Peroxyacetyl Nitrate}

\author{
Troy L. Mazely, ${ }^{\dagger}$ Randall R. Friedl, and Stanley P. Sander* \\ Jet Propulsion Laboratory, California Institute of Technology, 4800 Oak Grove Drive, \\ Pasadena, California 91109
}

Received: November 4, 1994; In Final Form: February 14, $1995^{\circ}$

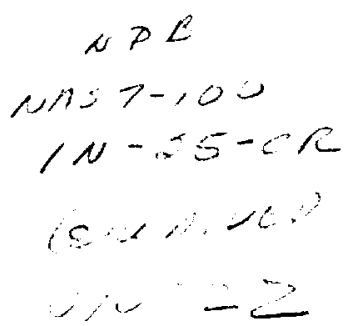

$\sim P Q$

U⿻: $7-10$

NASA-CR-203214

Peroxyacetyl nitrate (PAN) vapor was photolyzed at $248 \mathrm{~nm}$, anu ule $\mathrm{NU}_{2}$ pnotoproduct was detected by laser-induced fluorescence. The quantum yield for the production of $\mathrm{NO}_{2}$ from $\mathrm{PAN}$ photolysis was determined by comparison to $\mathrm{HNO}_{3}$ photolysis data taken under identical experimental conditions. The average of data collected over a range of total pressures, precursor concentrations, and buffer gases was $0.83 \pm 0.09$ for the $\mathrm{NO}_{2}$ quantum yield, where the statistical uncertainty is 2 standard deviations.

\section{Introduction}

Peroxyacetyl nitrate or PAN, $\mathrm{CH}_{3} \mathrm{C}(\mathrm{O}) \mathrm{OONO}_{2}$, is a wellknown and important component of the atmosphere. It was first detected in urban photochemical smog in the early $1960 \mathrm{~s}$. Subsequent field observations and laboratory studies have concluded that PAN is primarily formed in situ from reactions of $\mathrm{NO}_{2}$ with oxidation products of small nonmethane hydrocarbons. $^{2}$ PAN has received much attention in the literature because it is a known eye irritant and phytotoxin in polluted urban air and serves as a long range transport vehicle of $\mathrm{NO}_{x}$. PAN has been detected globally from ground level to $10 \mathrm{~km}$ altitude ${ }^{3}$ at concentrations that are significant relative to the total $\mathrm{NO}_{y}$ budget. ${ }^{4-10}$ In the lower troposphere the concentration of PAN is controlled by thermal decomposition, which is strongly temperature dependent. ${ }^{11-13}$ At higher altitudes, PAN has a long thermal lifetime and other loss mechanisms become important. Because of the resistance of PAN to chemical attack by scavengers such as $\mathrm{OH}$ and $\mathrm{Cl}^{14-17}$ and the stability against heterogeneous reaction, ${ }^{18-20}$ photolysis is the dominant sink for PAN at altitudes greater than approximately $7 \mathrm{~km} .{ }^{17}$

Although the ultraviolet absorption cross sections of PAN have been measured by several investigators with better than $10 \%$ precision from 200 to $300 \mathrm{~nm},{ }^{17.21 .22}$ there are no experimental measurements of the product yields. Current data assessments employed in atmospheric models recommend only one PAN photolysis channel, ${ }^{1.4}$ namely,

$$
\mathrm{PAN}+h v-\mathrm{CH}_{3} \mathrm{C}(\mathrm{O}) \mathrm{OO}+\mathrm{NO}_{2}, \lambda_{\mathrm{T}}=990 \pm 240 \mathrm{~nm}
$$

where the threshold wavelength is at $298 \mathrm{~K}$. The low threshold for dissociation allows for the possibility of large amounts of internal energy disposal in the products. If the $\mathrm{NO}_{2}$ product from channel la is sufficiently excited, it may undergo secondary dissociation, forming $\mathrm{NO}$ and $\mathrm{O}$.

$$
\begin{aligned}
& \mathrm{PAN}+h v \rightarrow \\
& \quad \mathrm{CH}_{3} \mathrm{C}(\mathrm{O}) \mathrm{OO}+\mathrm{NO}+\mathrm{O}\left({ }^{3} \mathrm{P}\right), \lambda_{\mathrm{T}}=281 \pm 35 \mathrm{~nm}(1 \mathrm{~b}) \\
& \mathrm{PAN}+h \nu \rightarrow \\
& \quad \mathrm{CH}_{3} \mathrm{C}(\mathrm{O}) \mathrm{OO}+\mathrm{NO}+\mathrm{O}\left({ }^{1} \mathrm{D}\right), \lambda_{\mathrm{T}}=195 \pm 15 \mathrm{~nm}(1 \mathrm{c})
\end{aligned}
$$

\footnotetext{
* To whom correspondence should be addressed.

+ Present address: Department of Earth System Sciences, University of California, Irvine, CA 92717

${ }^{\otimes}$ Abstract published in Advance ACS Abstracts, April 15, 1995.
}

Other energetically accessible channels for the ultraviolet photolysis of PAN can be proposed. One channel that is direct, and nearly isoenergetic with channel $1 \mathrm{a}$, is

$$
\mathrm{PAN}+h v \rightarrow \mathrm{CH}_{3} \mathrm{C}(\mathrm{O}) \mathrm{O}+\mathrm{NO}_{3}, \lambda_{\mathrm{T}}=1025 \pm 215 \mathrm{~nm}
$$

The energy thresholds for the related reactions involving secondary dissociation of the $\mathrm{NO}_{3}$ are

$$
\begin{aligned}
& \mathrm{PAN}+h v \rightarrow \\
& \quad \mathrm{CH}_{3} \mathrm{C}(\mathrm{O}) \mathrm{O}+\mathrm{NO}_{2}+\mathrm{O}\left({ }^{3} \mathrm{P}\right), \lambda_{\mathrm{T}}=375 \pm 30 \mathrm{~nm}(2 \mathrm{~b}) \\
& \mathrm{PAN}+h v \rightarrow \\
& \quad \mathrm{CH}_{3} \mathrm{C}(\mathrm{O}) \mathrm{O}+\mathrm{NO}_{2}+\mathrm{O}\left({ }^{1} \mathrm{D}\right), \lambda_{\mathrm{T}}=235 \pm 10 \mathrm{~nm}(2 \mathrm{c})
\end{aligned}
$$

PAN may also dissociate through concerted reactions, such as

$$
\begin{aligned}
& \mathrm{PAN}+h v \rightarrow \mathrm{CH}_{3}+\mathrm{CO}_{2}+\mathrm{NO}_{3}, \lambda_{\mathrm{T}}=1395 \pm 340 \mathrm{~nm} \text { (3a) } \\
& \mathrm{PAN}+h v \rightarrow \\
& \mathrm{CH}_{3}+\mathrm{CO}_{2}+\mathrm{NO}_{2}+\mathrm{O}\left({ }^{3} \mathrm{P}\right), \lambda_{\mathrm{T}}=415 \pm 30 \mathrm{~nm}(3 \mathrm{~b}) \\
& \mathrm{PAN}+h v \rightarrow \\
& \mathrm{CH}_{3}+\mathrm{CO}_{2}+\mathrm{NO}_{2}+\mathrm{O}\left({ }^{1} \mathrm{D}\right), \lambda_{\mathrm{T}}=250 \pm 10 \mathrm{~nm} \text { (3c) }
\end{aligned}
$$

or

$$
\begin{aligned}
& \mathrm{PAN}+h v \rightarrow \\
& \quad \mathrm{CH}_{3} \mathrm{C}(\mathrm{O})+\mathrm{O}_{2}+\mathrm{NO}_{2}, \lambda_{\mathrm{T}}=445 \pm 35 \mathrm{~nm}(4 \mathrm{a}) \\
& \mathrm{PAN}+h v \rightarrow \\
& \mathrm{CH}_{3} \mathrm{C}(\mathrm{O})+\mathrm{O}_{2}+\mathrm{NO}+\mathrm{O}\left({ }^{3} \mathrm{P}\right), \lambda_{\mathrm{T}}=209 \pm 10 \mathrm{~nm}(4 \mathrm{~b}) \\
& \mathrm{PAN}+h v \rightarrow \\
& \mathrm{CH}_{3} \mathrm{C}(\mathrm{O})+\mathrm{O}_{2}+\mathrm{NO}+\mathrm{O}\left({ }^{1} \mathrm{D}\right), \lambda_{\mathrm{T}}=157 \pm 3 \mathrm{~nm}(4 \mathrm{c})
\end{aligned}
$$

Several exothermic dissociation channels may also be conceived which require the rearrangement and breaking of several bonds. Examples include

$$
\begin{aligned}
& \text { PAN } \stackrel{h v}{\longrightarrow} \\
& \mathrm{CH}_{3} \mathrm{O}+\mathrm{CO}_{2}+\mathrm{NO}_{2}, \quad \Delta H_{\mathrm{rxn}}=-20 \pm 5 \mathrm{kcal} / \mathrm{mol}
\end{aligned}
$$




$$
\mathrm{PAN} \stackrel{\stackrel{h v}{\longrightarrow}}{\mathrm{CH}_{3} \mathrm{O}_{2}}+\mathrm{CO}_{2}+\mathrm{NO}, \Delta H_{\mathrm{rxn}}=-6 \pm 5 \mathrm{kcal} / \mathrm{mol}
$$

where $\Delta H_{\mathrm{rxn}}$ is at $298 \mathrm{~K}$. The large uncertainties in the energetics of many of the above channels are a consequence of imprecision in the experimental heats of formation of $\mathrm{CH}_{3} \mathrm{C}$ (O)O $(-52 \pm 3 \mathrm{kcal} / \mathrm{mol}), \mathrm{CH}_{3} \mathrm{C}(\mathrm{O}) \mathrm{O}_{2}(-41 \pm 5 \mathrm{kcal} / \mathrm{mol})$, and PAN ( $-62 \pm 5 \mathrm{kcal} / \mathrm{mol}){ }^{23-27}$

Because PAN has a structureless ultraviolet absorption spectrum, one expects the photodissociation pathways to be direct. Consequently, channels 5 and 6 and other mechanisms which require rearrangement of an excited intermediate prior to dissociation are not anticipated to be primary photolysis routes. In the Earth's atmosphere some of the photodissociation pathways lead effectively to the same products due to rapid secondary chemistry. For instance, the acetyl radical produced in channel 4 will rapidly combine with $\mathrm{O}_{2}$ to form the same organic product, peroxy acetyl radical, as obtained from channel 1. In addition, the unstable $\mathrm{CH}_{3} \mathrm{C}(\mathrm{O}) \mathrm{O}$ product of channel 2 will decompose into $\mathrm{CO}_{2}$ and $\mathrm{CH}_{3}$, yielding the same products as channel $3 .^{24}$ On account of these pathways, the atmospheric roles of the various photolytic channels reduce to two general possibilities. First, if the photodissociation is through channel la or $4 \mathrm{a}, \mathrm{NO}_{2}$ and the peroxy acetyl radical are ultimately regenerated. Since PAN is largely formed in the atmosphere from the three-body combination of these two products, this reaction pathway results in a chemical null cycle and the role of PAN at higher altitudes is solely as a reservoir and transport vehicle of nitrogen oxides. On the other hand, if the photolysis is through other channels, especially channel $2 a$, new chemical pathways arise which produce odd oxygen. In particular, the $\mathrm{NO}_{3}$ formed will dissociate into $\mathrm{NO}_{2}$ and $\mathrm{O}$, either by solar photolysis or by unimolecular dissociation of the excited product, and the organic photoproducts will decompose to $\mathrm{CO}_{2}$ and $\mathrm{CH}_{3}$. Since the oxidation of the methyl radical also produces odd oxygen, both the organic and nitrogen containing photoproducts will affect the ozone budget.

In this work we have investigated $\mathrm{NO}_{2}$ production from the photolysis of PAN at $248 \mathrm{~nm}$. The $\mathrm{NO}_{2}$ was detected by laserinduced fluorescence (LIF). By comparison to the $\mathrm{NO}_{2}$ production from the photolysis of $\mathrm{HNO}_{3}$ under identical experimental conditions, we have obtained a relative quantum yield for the production of $\mathrm{NO}_{2}$. The implications of these results for atmospheric PAN chemistry will be discussed.

\section{Experimental Section}

A schematic of the experimental apparatus is shown in Figure 1. Gaseous samples of $\mathrm{HNO}_{3}$ and PAN were introduced into the flowing system by passing a carrier gas ( $\mathrm{He}, \mathrm{Ar}, \mathrm{N}_{2}$, or $\mathrm{O}_{2}$ ) through a Pyrex reservoir containing PAN or $\mathrm{HNO}_{3}$. In the case of $\mathrm{HNO}_{3}$ the reservoir contained a neat solution of nitric acid, prepared by collecting the vacuum distillate of a 50:50 by volume mixture of $95 \% \mathrm{H}_{2} \mathrm{SO}_{4}$ with $\mathrm{NaNO}_{3}$. The $\mathrm{HNO}_{3}$ was maintained at $0{ }^{\circ} \mathrm{C}$ by placing the sample in an ice bath.

The $\mathrm{HNO}_{3}$ vapor concentration was determined by optical absorption at $254 \mathrm{~nm}$ in a $50 \mathrm{~cm}$ long absorption cell upstream of the photolysis cell. The pressure in the $\mathrm{HNO}_{3}$ reservoir and absorption cell (25-150 Torr) was adjusted using a Teflon needle valve located between the absorption cell and the photolysis cell and monitored with an MKS Baratron capacitance manometer. The $\mathrm{HNO}_{3}$ concentrations derived from the optical measurements agreed well with estimates based on the known vapor pressure of $\mathrm{HNO}_{3}$. All flow rates were determined using calibrated flow meters.
The PAN samples were prepared by the method of Gaffney et al. ${ }^{28}$ In accordance with this procedure the synthesized PAN was extracted from an acidic aqueous solution into $n$-tridecane $\left(\mathrm{C}_{13} \mathrm{H}_{28}\right)$. The organic solution was then washed with $0^{\circ} \mathrm{C}$ water three times to remove water soluble impurities. The PAN vapor was introduced into the photolysis cell by one of two methods. The organic solution was used directly as a source of gaseous PAN by transferring it to a reservoir and bubbling the buffer gas through the sample which was kept in a $0^{\circ} \mathrm{C}$ ice bath. Because of the negligible vapor pressure of tridecane compared to PAN, this method provided essentially pure PAN in the gas phase. Fourier transform infrared spectra taken of the gaseous samples confirmed that the fraction of PAN in the vapor was greater than $98 \%$, in agreement with previous investigators. ${ }^{28.29}$ For some trials, multiple samples of pure PAN were collected by passing the vapor from the tridecane solution through a reservoir immersed in liquid nitrogen. The solid PAN, now containing only a trace amount of tridecane, was used as the sample for photolysis experiments. Appropriate precautions were taken in handling the pure PAN samples to protect against possible explosive decomposition. During photolysis experiments the pure PAN samples were maintained at a temperature of either $-48^{\circ} \mathrm{C}$ using a $n$-hexanol slush or approximately -20 ${ }^{\circ} \mathrm{C}$ using an aqueous $\mathrm{CaCl}_{2}$ slush. The PAN was found to be quite stable at these temperatures. The advantages of the second operation were that (1) large quantities of PAN could be synthesized and collected at one time providing a longer lasting batch and (2) a more stable PAN vapor pressure was maintained compared to direct extraction from the tridecane. Both methods yielded identical results within the experimental error.

The vapor pressure of the PAN was determined by optical absorption through a $50 \mathrm{~cm}$ absorption cell. The $214 \mathrm{~nm}$ line of a $Z_{n}$ lamp was employed as the light source, and the total pressure in the absorption cell was varied between 5 and 40 Torr. The optical cross sections for PAN have substantial more uncertainty as compared to $\mathrm{HNO}_{3}$. An average of experimental results from three independent studies was utilized to convert the absorbance to a concentration. ${ }^{17.21 .22}$ As will be discussed further in the Uncertainty Analysis part of the Results section, the magnitude of the absolute concentrations of PAN will vary, depending on which experimental sets of cross sections are utilized; however, the measured relative quantum yield of $\mathrm{NO}_{2}$ production is independent of whichever PAN absorption spectrum is employed in the analysis. As an additional test to confurm our ability to accurately measure the concentration of PAN, absorption measurements were also made at $254 \mathrm{~nm}$. The calculated concentrations at the two wavelengths agreed well; however, the $214 \mathrm{~nm}$ determination was preferred because the optical density of the PAN at this wavelength closely matched that of the $\mathrm{HNO}_{3}$ at $254 \mathrm{~nm}$ using the same absorption cell path length.

The concentrations of the gases in the quartz photolysis cell were reduced relative to those in the upstream absorption cell by injection of additional buffer gas in a mixing manifold located between the cells. The concentration of $\mathrm{HNO}_{3}$ in the photolysis cell ranged between $(0.1-45.0) \times 10^{14} \mathrm{~cm}^{-3}$ and that of PAN was varied between $(0.5-5.0) \times 10^{14} \mathrm{~cm}^{-3}$. In all experiments, the partial pressures of the precursors were maintained low enough that the fluorescence quenching was controlled solely by the carrier gas. ${ }^{30}$ The relative optical densities of PAN and $\mathrm{HNO}_{3}$ in the photolysis cell were maintained within approximately an order of magnitude of each other. The total pressures in the photolysis cell ranged from 1 to 16 Torr. Depending on total pressure, the flow rate into the cell was 


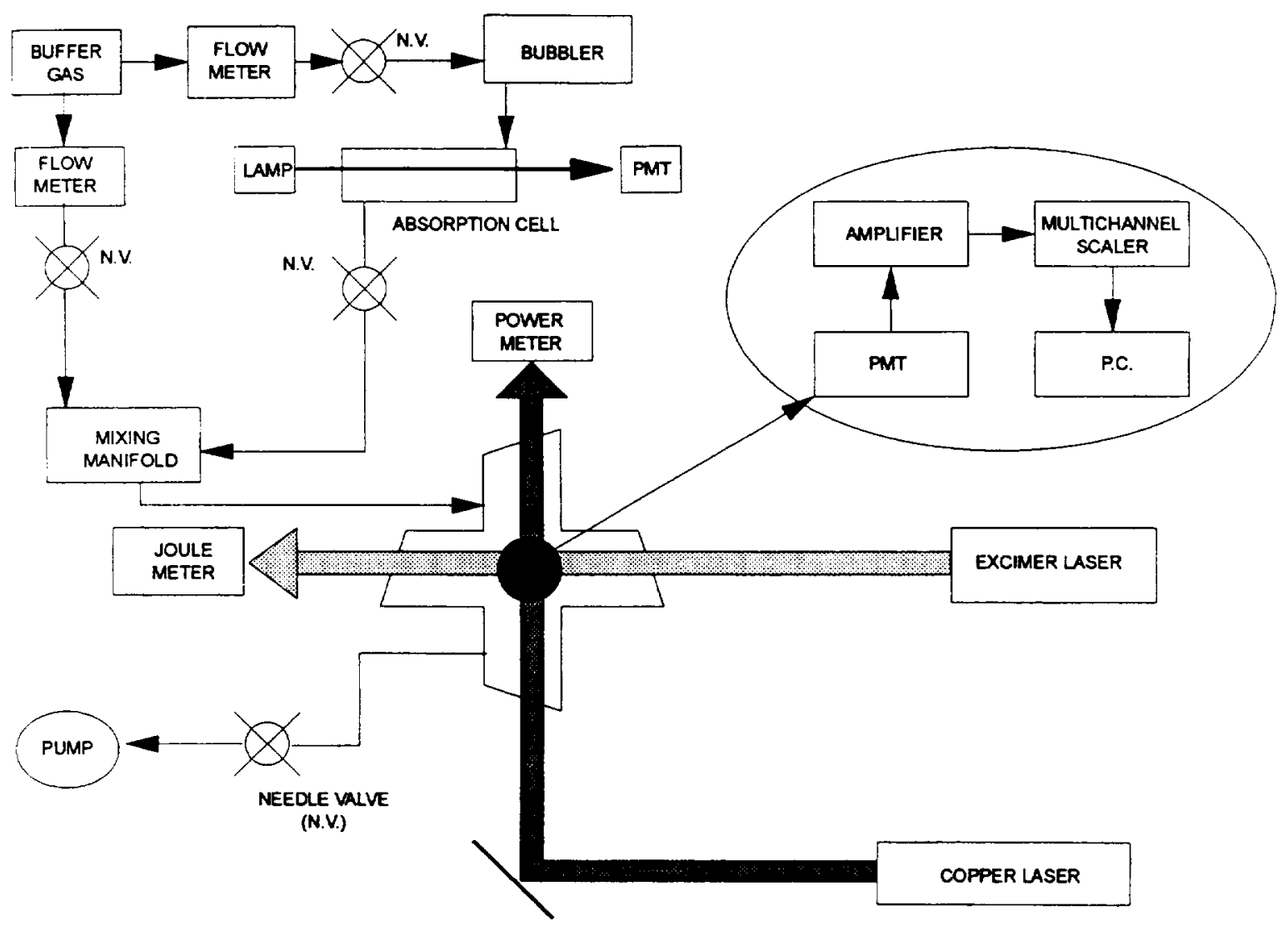

Figure 1. Schematic of the experimental apparatus

maintained between 250 and $4000 \mathrm{sccm}$ which was adequate to remove photoproducts from the detector viewing zone between photolysis laser shots.

The weakly focused output of an excimer laser (Questek Model 2240) operating at $248 \mathrm{~nm}$ and at a pulse repetition rate of $30 \mathrm{~Hz}$ was used to photolyze the precursors. The energy density ranged from 35 to $75 \mathrm{~mJ} / \mathrm{cm}^{2}$ per pulse and was monitored with a Joule meter (Scientech P50). Under these conditions the photolytic signal was observed to be linear with laser pulse energy. Typically $25000-50000$ laser shots were averaged for one experiment.

A pulsed copper vapor laser (CVL: Oxford model CU15A) operating at an adjustable repetition rate between 10 to $20 \mathrm{kHz}$ was utilized for LIF detection of $\mathrm{NO}_{2}$. The $578 \mathrm{~nm}$ output from the CVL was eliminated by passage of the beam through two short wavelength pass filters. The transmitted $511 \mathrm{~nm}$ line was directed through a telescope to reduce the diameter of the beam to approximately $0.5 \mathrm{~cm}$. The weakly convergent beam was then sent to the photolysis cell. The output power of the laser was monitored and found to vary less than $1 \%$ over the course of an experimental run.

The LIF signal was detected by a cooled photomultiplier tube (PMT: Burle C31034-02) that was oriented perpendicular to the laser beam axes. The LIF signal was amplified, discriminated, and counted on a multichannel scaler card (MCS: Canberra Accuspec) configured with bin widths of either 5 or $10 \mu \mathrm{s}$. A $550 \mathrm{~nm}$ long pass filter was placed in front of the PMT to block excimer and CVL laser scatter. An LIF detection sensitivity of approximately $3 \times 10^{9} \mathrm{NO}_{2} \mathrm{~cm}^{-3}$ was achieved with signal averaging of $25000 \mathrm{CVL}$ pulses.

The timing and synchronization of the two lasers were controlled by a high-frequency master clock $(10-20 \mathrm{kHz})$, a frequency divider circuit, and two delay generators. The master clock pulses were used to trigger the CVL, and the appropriately delayed low-frequency ( $30 \mathrm{~Hz}$ ) outputs of the frequency divider were used to trigger the excimer and the MCS data collection. This arrangement allowed for selection of a wide range of delay times between the excimer laser pulse, the copper vapor laser pulse, and the signal collection.

\section{Results}

Experimental Observations. Fluorescence data following photolysis of PAN and $\mathrm{HNO}_{3}$ were collected at total pressures from 1 to 16 Torr in four different carrier gases: $\mathrm{He}, \mathrm{Ar}, \mathrm{N}_{2}$, and $\mathrm{O}_{2}$. The high repetition frequency of the probe laser resulted in acquisition of an LIF data point every 50 to $100 \mu \mathrm{s}$, depending on selected CVL repetition rate. The rapid temporal sampling of the $\mathrm{NO}_{2}$ produced very well resolved profiles of $\mathrm{NO}_{2}$ loss (i.e., diffusion and flow) from the viewing zone. In Figure $2 \mathrm{~A}$ raw data from $\mathrm{HNO}_{3}$ photolysis in 3.5 Torr of Ar are shown. The probe laser was operating at $10 \mathrm{kHz}$, and the LIF signal is clearly seen above the more rapidly decaying background noise, which originates from cell and filter fluorescence induced by the excimer laser. The background noise was removed from the data, and the residual LIF signal from the probe laser is shown in Figure 2B. The line in Figure $2 \mathrm{~B}$ is a fourth-order polynomial regression to guide the eye. The temporal profile of the probe signal was analyzed until the $\mathrm{NO}_{2}$ photoproduct completely left the detection viewing zone, at which time the LIF signal was constant and finite due to background $\mathrm{NO}_{2}$ from slight decomposition of the precursors ( $\mathrm{HNO}_{3}$ and $\left.\mathrm{PAN}\right)$ and leakage of the probe laser light through the detection filters. The background probe signal was removed from the data to obtain the actual signal from photolysis. The error bars in Figure 2 represent the statistical (photon) noise of the data. 

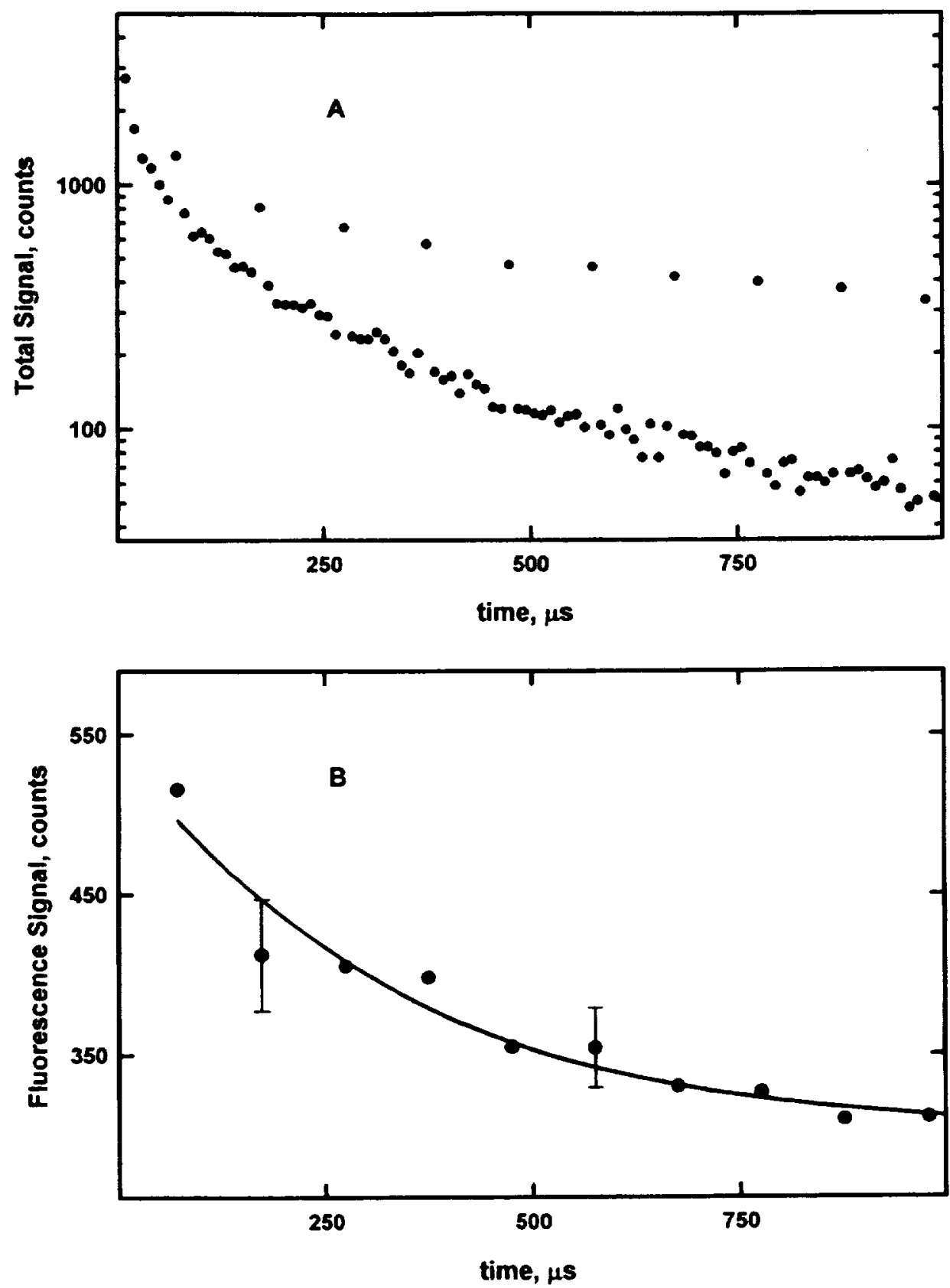

Figure 2. (A) Raw data from the photolysis of $2.9 \times 10^{15} \mathrm{HNO}_{3} \mathrm{~cm}^{-3}$ in $3.5 \mathrm{Torr}$ of Ar. The signal from 16000 excimer shots was summed to obtain this temporal profile. The densely spaced lower trace is from cell and filter fluorescence induced by the excimer. The upper trace is LIF from the probe laser superimposed on the background noise. (B) The background noise from the excimer is removed from the data in part A. The residual signal is the LIF solely due to the probe laser. The signal consists of three components; (1) $\mathrm{NO}_{2}$ generated from $\mathrm{HNO}_{3}$ photolysis, (2) $\mathrm{NO}_{2}$ from slight $\mathrm{HNO}_{3}$ decomposition, and (3) probe laser scatter through the optical filters.

Under otherwise identical experimental conditions, the loss rates of the LIF signals generated from $\mathrm{PAN}$ and $\mathrm{HNO}_{3}$ were the same. This is illustrated in Figure 3A, where all sources of background signal have been removed from the data. In order to determine the relative production of $\mathrm{NO}_{2}$ from each of the precursors, absolute signals from each, at set delays between pump and probe pulses, were ratioed, as shown in Figure 3B, and an average of these independent values yielded the relative yield of $\mathrm{NO}_{2}$. The normalization of this average to the initial optical densities of the precursors converts this quantity to a relative quantum yield. Details are presented in the next section. Typically, data were averaged from the first probe pulse after the photolysis, $t \leq 50 \mu \mathrm{s}$, to approximately $1500 \mu \mathrm{s}$ after the photolysis to determine the average relative signal. Because of the rapid loss of the $\mathrm{NO}_{2}$ photoproducts at early time, the "point by point" analysis, shown in Figure 3B, results in better precision than an analysis based on extrapolating the LIF temporal profile back to the time of the pump pulse and comparing the calculated nascent signals.

The best LIF signal to noise ratios were obtained with Ar as a carrier, due to its less efficient fluorescence quenching compared to $\mathrm{O}_{2}$ and $\mathrm{N}_{2}$. Although Helium has an electronic quenching rate coefficient similar to Argon, ${ }^{30}$ its diffusion rate is nearly 4 times as great. ${ }^{31}$ The rapid diffusion characteristic limited the temporal range over which useful LIF data could be obtained in He, except at higher total pressures, i.e., $>10$ Torr, where increased fluorescence quenching became the major limitation in all the buffer gases. Relaxation rates of excited 

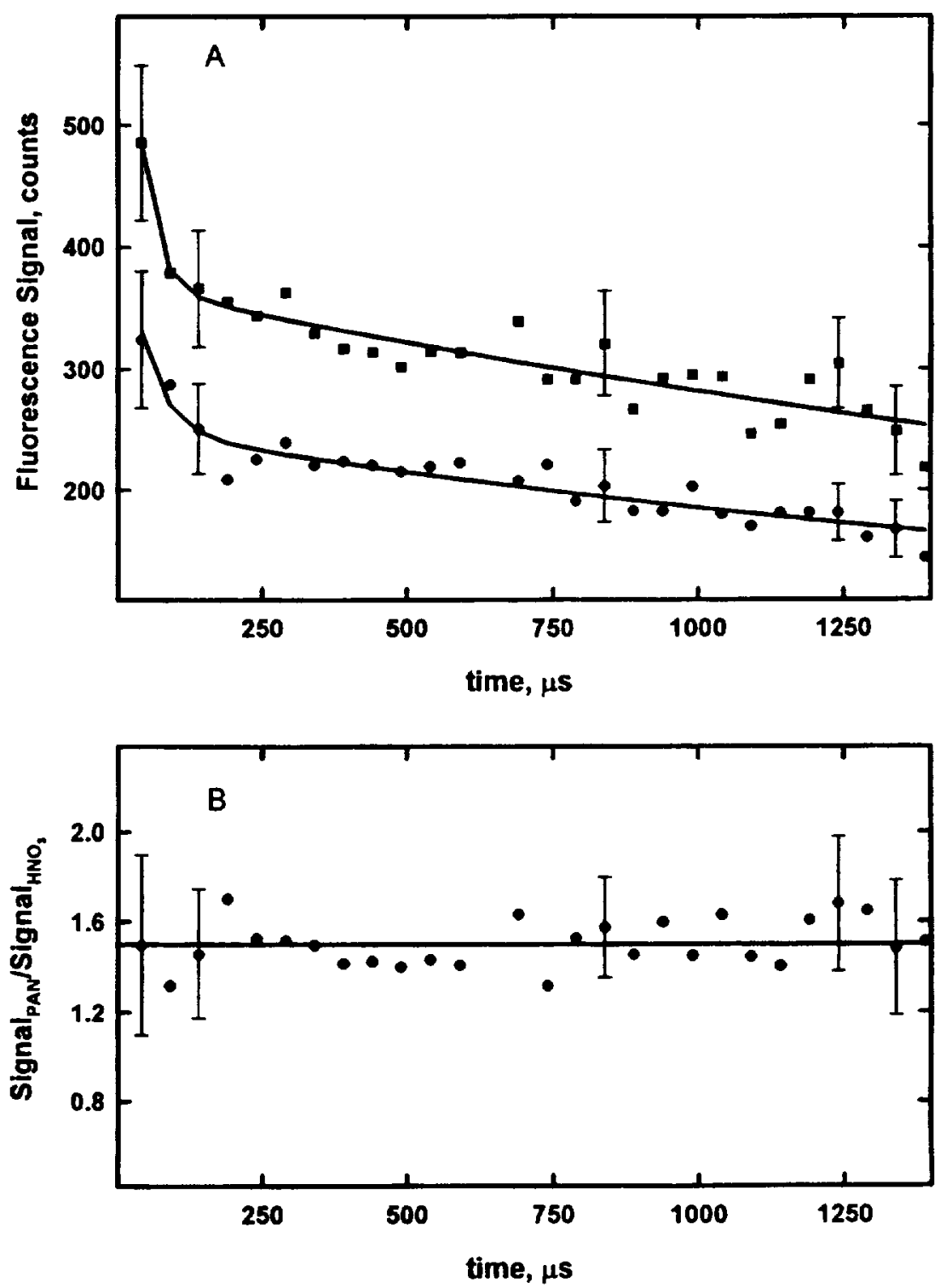

Figure 3. (A) $\mathrm{NO}_{2}$ LIF signal vs time is shown for photolysis of similar optical densities of PAN $\left(3.2 \times 10^{14} \mathrm{~cm}^{-3}\right)$ and $\mathrm{HNO}_{3}\left(1.0 \times 10^{15} \mathrm{~cm}^{-3}\right)$ in 7 Torr of $\mathrm{O}_{2}$. The decay of the signal is largely due to diffusion. Solid lines through the data are biexponential fits to the data which provide a visual guide. (B) Relative signal strengths of $\mathrm{NO}_{2}$ fluorescence from PAN and $\mathrm{HNO}_{3}$. The average of the relative signal from data taken between 0 and $1400 \mu \mathrm{s}$ after the excimer pulse is $1.50 \pm 0.30$, where the error bar is two standard deviations in experimental precision. The employment of eq 9 converts the signal ratio to a quantum yield of $0.75 \pm 0.15$.

$\mathrm{NO}_{2}$ in the presence of different colliders has been discussed previously. ${ }^{32}$ Under all conditions, loss of $\mathrm{NO}_{2}$ by secondary chemical reactions was negligible.

Our previous investigations of $\mathrm{HNO}_{3}$ photolysis at $248 \mathrm{~nm}$ revealed that the nascent $\mathrm{NO}_{2}$ produced from $\mathrm{HNO}_{3}$ is internally excited. ${ }^{32}$ Most of the $\mathrm{NO}_{2}$ is produced in the $\mathrm{A}\left({ }^{2} \mathrm{~B}_{2}\right)$ and $\mathrm{B}\left({ }^{2} \mathrm{~B}_{1}\right)$ states and undergoes rapid relaxation through the higher vibrational levels of the $\mathrm{X}\left({ }^{2} \mathrm{~A}_{1}\right)$ state. On the basis of observations of the early time profile of the fluorescence from PAN, we also conclude that the majority of the nascent $\mathrm{NO}_{2}$ from PAN photolysis is also electronically excited. At total pressures below 3 Torr, this excitation complicated the early time interpretation of the LIF signal in all of the buffer gases except for $\mathrm{O}_{2}$ whose vibrational collisional quenching of $\mathrm{NO}_{2}$ in the $\mathrm{X}\left({ }^{2} \mathrm{~A}_{1}\right)$ state is markedly more efficient. ${ }^{32}$ This internal excitation, combined with faster diffusional loss of the $\mathrm{NO}_{2}$, hindered data acquisition at the lower pressures. A consideration of effects associated with diffusion, fluorescence quenching, and collisional deactivation of the hot nascent $\mathrm{NO}_{2}$ indicated that the maximum signal to noise ratio was achieved at a total pressure of approximately 7 Torr. Consequently, the majority of the data was taken at this pressure.

Quantum Yield Determination Methodology. The nascent $\mathrm{NO}_{2}$ concentration, $\left[\mathrm{NO}_{2}\right]_{i}$, produced from monochromatic photolysis of a precursor gas, $i$, may be expressed by the following:

$$
\left[\mathrm{NO}_{2}\right]_{\mathrm{i}}=\Lambda \phi_{\mathrm{i}}^{\mathrm{NO}_{2}}\left(\lambda_{\text {photo }}\right)[\mathrm{i}] \sigma_{\mathrm{i}}\left(\lambda_{\text {photo }}\right)
$$

where $\lambda_{\text {photo }}$ is the photolysis wavelength. The $\mathrm{NO}_{2}$ quantum yield, $\phi_{1}^{\mathrm{NO}_{3}}$, is defined as the ratio of the total number of $\mathrm{NO}_{2}$ molecules produced relative to the number of photons absorbed by the precursor, $i$, which has an initial concentration, [i], and optical cross section, $\sigma_{i}\left(\lambda_{\text {photo }}\right)$. The quantity $\Lambda$ is a detection response function and depends on the energies of both the pump and probe lasers, the photon detection geometry, and, in the case of fluorescence detection, the extent of collisional quenching. The direct determination of $\Lambda$ is, in general, very difficult, largely due to the spatial inhomogeneities of the energy in the laser beams. For this reason, a relative measurement scheme 


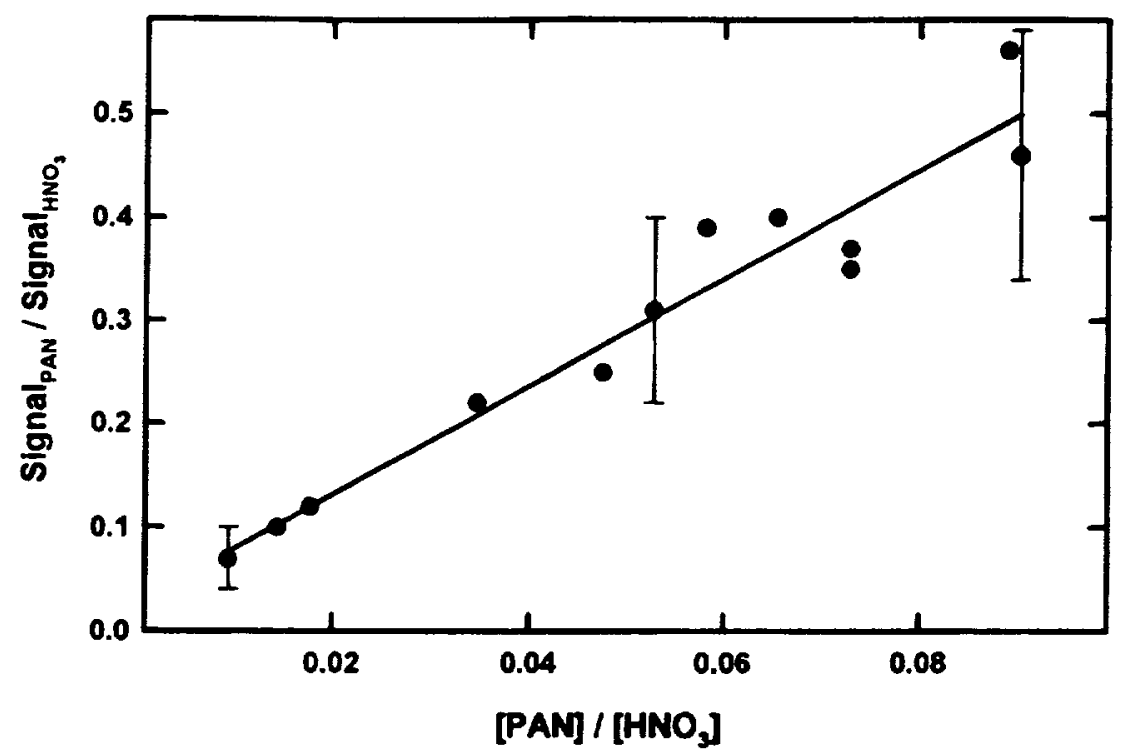

Figure 4. The relative fluorescent signals of $\mathrm{NO}_{2}$ from $\mathrm{PAN}$ and $\mathrm{HNO}_{3}$ photolyses at $248 \mathrm{~nm}$ in 7 Torr of $\mathrm{Ar}$ as a function of the corresponding relative concentrations of each precursor. Each data point represents a temporally averaged ratio of LIF signal, similar to those illustrated in Figure $2 \mathrm{~A}$. The slope of the solid line is proporional to $\phi_{\mathrm{PAN}}^{\mathrm{NO}}$. The value obtained from this plot for the quantum yield is $0.84 \pm 0.09$, where the error is two standard deviations in data precision.

was utilized in order to determine the quantum yield of $\mathrm{NO}_{2}$ production from PAN photolysis.

The photolysis of a reference gas whose optical cross section and $\mathrm{NO}_{2}$ quantum yield are known may be employed as a calibrant in determining the quantum yield of the molecule of interest. By measuring the relative $\mathrm{NO}_{2}$ production from these two species, under otherwise identical experimental conditions, the quantum yield for the gas under study is obtained without the direct need for knowledge of $\Lambda$. The photolysis of $\mathrm{HNO}_{3}$ was chosen as a calibrant to determine the quantum yield of $\mathrm{NO}_{2}$ from PAN. The relative $\mathrm{NO}_{2}$ concentrations produced from each of the experiments is related to the quantum yield by the following expression:

$$
\frac{\left[\mathrm{NO}_{2}\right]_{\mathrm{PAN}}}{\left[\mathrm{NO}_{2}\right]_{\mathrm{HNO}_{3}}}=\frac{S_{\mathrm{PAN}}(\tau)}{S_{\mathrm{HNO}_{3}}(\tau)}=\frac{\phi_{\mathrm{PAN}}^{\mathrm{NO}_{2}}\left(\lambda_{\text {photo }}\right)}{\phi_{\mathrm{HNO}_{3}}^{\mathrm{NO}_{2}}\left(\lambda_{\text {photo }}\right)} \frac{[\mathrm{PAN}]}{\left[\mathrm{HNO}_{3}\right]} \frac{\sigma_{\mathrm{PAN}}\left(\lambda_{\text {photo }}\right)}{\sigma_{\mathrm{HNO}_{3}}\left(\lambda_{\text {photo }}\right)}
$$

where $\Lambda$ has now been eliminated by ratioing the two. In eq $8, S_{\mathrm{i}}(\tau)$ is the fluorescence signal from each precursor at time, $\tau$, after photolysis. Rearrangement gives

$$
\phi_{\mathrm{PAN}}^{\mathrm{NO}_{2}}\left(\lambda_{\text {photo }}\right)=\phi_{\mathrm{HNO}_{3}}^{\mathrm{NO}_{2}}\left(\lambda_{\text {photo }}\right) \frac{S_{\mathrm{PAN}}(\tau)}{S_{\mathrm{HNO}_{3}}(\tau)} \frac{\left[\mathrm{HNO}_{3}\right]}{[\mathrm{PAN}]} \frac{\sigma_{\mathrm{HNO}_{3}\left(\lambda_{\text {photo }}\right)}}{\sigma_{\mathrm{PAN}}\left(\lambda_{\text {photo }}\right)}
$$

Equation 9 is the fundamental equation to convert the raw data to a quantum yield. In eq 9 the experimental observables are the relative concentrations and the relative signals. If these quantities are plotted against one another, the slope is proportional to the relative quantum yield. An example of this analysis is shown is Figure 4, where each data point was obtained by the analysis illustrated in Figure 3. In order to convert this slope into a relative quantum yield, the optical cross sections of each precursor at both the photolysis and, in the present case, absorption wavelengths must be known. LIF signals were observed at sufficiently long times following the excimer pulse that the all the $\mathrm{NO}_{2}$ produced from both $\mathrm{HNO}_{3}$ and PAN photolysis was fully vibrationally relaxed. Plots of the type shown in Figure 4 generally showed small y-intercepts. Although eq 9 suggests that the $y$-intercepts should be zero, leastsquares slopes were used to derive the quantum yields because the intercepts were randomly distributed and the contribution of the nonzero intercepts to the uncertainty were negligible compared with the random error.

Uncertainty Analysis. The ultraviolet optical cross sections for PAN have been independently measured by several investigators. Senum et al. ${ }^{21}$ recorded the absorption spectrum from 200 to $300 \mathrm{~nm}$, and values were tabulated every $5 \mathrm{~nm}$ with an assigned uncertainty of $8 \%$. An interpolated fit of their data yields values of $(12.0 \pm 1.0) \times 10^{-20} \mathrm{~cm}^{2}$ molecule ${ }^{-1}$ and (123 $\pm 10) \times 10^{-20} \mathrm{~cm}^{2}$ molecule ${ }^{-1}$ at 248 and $214 \mathrm{~nm}$, respectively, which are the wavelengths employed in the present study for photolysis and concentration determination by absorption. Slightly larger magnitudes at these two wavelengths have been obtained recently by Talukdar et al., ${ }^{17}(14.6 \pm 0.7) \times 10^{-20}$ and $(143 \pm 7) \times 10^{-20} \mathrm{~cm}^{2}$ molecule ${ }^{-1}$ and Libuda and Zabel, ${ }^{22}$ $14.6 \times 10^{-20}$ and $145 \times 10^{-20} \mathrm{~cm}^{2}$ molecule ${ }^{-1}$ (uncertainties for these values were not reported). Although the magnitude of the absolute cross sections differ between the earlier work of Senum $e t$ al. and the two more recent observations, the values of the relative cross sections agree well: the ratios of the reported cross section at $214 \mathrm{~nm}$ to that at $248 \mathrm{~nm}$ are $10.2 \pm$ $1.2,9.8 \pm 0.7$, and 9.9 for the results of Senum et al., Talukdar et al., and Libuda and Zabel, respectively. The accuracy of the relative measurements likely exceed those of the absolute ones because systematic uncertainties cancel. The average of the three cross-sectional data sets is

$$
\frac{\sigma_{\mathrm{PAN}}\left(\lambda_{\mathrm{abs}}=214 \mathrm{~nm}\right)}{\sigma_{\mathrm{PAN}}\left(\lambda_{\text {photo }}=248 \mathrm{~nm}\right)}=10.0 \pm 0.4
$$

where the uncertainty is 2 standard deviations in the average of the three data sets and the subscripts $a b s$ and photo refer to the absorption and photolysis wavelength, respectively.

In the present studies the initial precursor concentrations were obtained by measuring the optical absorbance at a particular absorption wavelength, $A\left(\lambda_{\text {abs }}\right)$, i.e.,

$$
A_{\mathrm{i}}\left(\lambda_{\mathrm{abs}}\right)=\sigma_{\mathrm{i}}\left(\lambda_{\mathrm{abs}}\right) L[\mathrm{i}]
$$


where $L$ is the cell path length. Replacing the concentration terms in eq 9 with the actual observable, the absorbance, yields

$$
\begin{aligned}
& \phi_{\mathrm{PAN}}^{\mathrm{NO}_{2}}\left(\lambda_{\text {photo }}\right)= \\
& \phi_{\mathrm{HNO}_{3}}^{\mathrm{NO}_{2}}\left(\lambda_{\text {photo }}\right) \frac{S_{\mathrm{PAN}}(\tau)}{S_{\mathrm{HNO}_{3}}(\tau)} \frac{A_{\mathrm{HNO}_{3}}\left(\lambda_{\text {abs }}\right)}{A_{\mathrm{PAN}}\left(\lambda^{*}{ }_{\text {abs }}\right)} \frac{\sigma_{\mathrm{PAN}}\left(\lambda^{*}{ }_{\mathrm{abs}}\right)}{\sigma_{\mathrm{PAN}}\left(\lambda_{\text {photo }}\right)} \frac{\sigma_{\mathrm{HNO}_{3}}\left(\lambda_{\text {photo }}\right)}{\sigma_{\mathrm{HNO}_{3}}\left(\lambda_{\text {abs }}\right)}
\end{aligned}
$$

Because the same absorption cell was employed in the measurement of the absorbance of each precursor, the cell path length cancels out of the expression. The use of different absorption wavelengths for $\mathrm{PAN}$ and $\mathrm{HNO}_{3}$ are distinguished by an asterisk in eq 12.

The absorption cross sections are better established for $\mathrm{HNO}_{3}$ than for PAN. The results of Johnston and Graham, ${ }^{33}$ Biaume, ${ }^{34}$ and Molina and Molina ${ }^{35}$ all agree well at 248 and $254 \mathrm{~nm}$. Biaume reported cross sections of $1.98 \times 10^{-20}$ and $1.95 \times$ $10^{-20} \mathrm{~cm}^{2}$ molecule ${ }^{-1}$ at the $\mathrm{Hg}$ lines at 248.48 and $253.65 \mathrm{~nm}$, respectively. These values was used for the analysis of our data. The estimated error of the $\mathrm{HNO}_{3}$ cross sections at these wavelengths is $1 \%$. These values result in the following ratio, where the uncertainty is 2 standard deviations,

$$
\frac{\sigma_{\mathrm{HNO}_{3}}\left(\lambda_{\text {photo }}\right)}{\sigma_{\mathrm{HNO}_{3}}\left(\lambda_{\text {abs }}\right)}=1.02 \pm 0.03
$$

Incorporating eqs 10 and 13 into eq 12 yields

$$
\phi_{\mathrm{PAN}}^{\mathrm{NO}_{2}}\left(\lambda_{\text {photo }}\right)=(10.2 \pm 0.5) \phi_{\mathrm{HNO}_{3}}^{\mathrm{NO}_{2}}\left(\lambda_{\text {photo }}\right) \frac{S_{\mathrm{PAN}}(\tau)}{S_{\mathrm{HNO}_{3}}(\tau)} \frac{A_{\mathrm{HNO}_{3}}\left(\lambda_{\mathrm{abs}}\right)}{A_{\mathrm{PAN}}\left(\lambda^{*}{ }_{\mathrm{abs}}\right)}
$$

The relative quantum yield from the photolyses of PAN and $\mathrm{HNO}_{3}$ has now been put into a functional form which is dependent on the experimental observables. The only remaining scaling quantity to convert the data to an absolute yield is $\phi_{\mathrm{HNO}}^{\mathrm{NO}_{2}}\left(\lambda_{\text {photo }}\right)$.

The photolysis of $\mathrm{HNO}_{3}$ has been studied at a variety of wavelengths. ${ }^{36-41}$ At a photolysis wavelength of $248 \mathrm{~nm}$ the following four channels are energetically allowed:

$$
\begin{gathered}
\mathrm{HNO}_{3}+h v \rightarrow \mathrm{NO}_{2}+\mathrm{OH}, \lambda_{\mathrm{T}} \leq 601 \mathrm{~nm} \\
\rightarrow \mathrm{O}\left({ }^{3} \mathrm{P}\right)+\mathrm{HONO}, \lambda_{\mathrm{T}} \leq 400 \mathrm{~nm} \\
\rightarrow \mathrm{H}\left({ }^{2} \mathrm{~S}\right)+\mathrm{NO}_{3}, \lambda_{\mathrm{T}} \leq 286 \mathrm{~nm} \\
\rightarrow \mathrm{H}\left({ }^{2} \mathrm{~S}\right)+\mathrm{NO}+\mathrm{O}_{2}, \lambda_{\mathrm{T}} \leq 278 \mathrm{~nm}
\end{gathered}
$$

where the threshold wavelengths are given at $0 \mathrm{~K}$. No $\mathrm{H}$ atom production has been detected from $\mathrm{HNO}_{3}$ photolysis over the wavelength range from 193 to $266 \mathrm{~nm},{ }^{36,37}$ indicating that both channels 17 and 18 are insignificant dissociation pathways at $248 \mathrm{~nm}$; however, channels 15 and 16 are both active ultraviolet photolysis channels for $\mathrm{HNO}_{3}$ with branching ratios that are strongly wavelength dependent. In the recent work of Turnipseed et al. ${ }^{37}$ which employed a relative quantum yield determination scheme similar to the present approach for PAN, values of $\phi_{\mathrm{HNO}_{3}}^{\mathrm{OH}}$ (and $\phi_{\mathrm{HNO}_{3}}^{\mathrm{O}}$ ) were reported to be $0.95 \pm 0.06(0.031 \pm$ $0.009), 0.90 \pm 0.11(0.20 \pm 0.03)$, and $0.33 \pm 0.09(0.81 \pm$ 0.13 ) at 248,222 , and $193 \mathrm{~nm}$, respectively. Schiffman et al ${ }^{41}$ also observed a decrease in $\phi_{\mathrm{HNO}_{3}}^{\mathrm{OH}}$ at lower photolysis wave-
TABLE 1

\begin{tabular}{cccccc}
\hline $\begin{array}{c}P, \\
\text { Torr }\end{array}$ & $\mathrm{M}$ & $\phi_{\mathrm{NO}_{2}}$ & $\begin{array}{c}\mathrm{HNO}_{3} \\
\text { runs }\end{array}$ & $\begin{array}{c}\mathrm{PAN} \\
\text { runs }\end{array}$ & $\begin{array}{c}{[\mathrm{PAN}]} \\
\times 10^{13} \mathrm{~cm}^{-3}\end{array}$ \\
\hline 1 & $\mathrm{O}_{2}$ & $0.90 \pm 0.25$ & 1 & 1 & 4.5 \\
3 & $\mathrm{Ar}$ & $0.84 \pm 0.08$ & 4 & 4 & $8.0-29.3$ \\
4 & $\mathrm{O}_{2}$ & $0.75 \pm 0.22$ & 6 & 6 & $2.6-25.8$ \\
7 & $\mathrm{O}_{2}$ & $0.75 \pm 0.15$ & 1 & 1 & 31.6 \\
7 & $\mathrm{Ar}$ & $0.84 \pm 0.09$ & 3 & 4 & $6.8-11.3$ \\
7 & $\mathrm{~N}_{2}$ & $0.80 \pm 0.20$ & 2 & 2 & $2.1-45.1$ \\
16 & $\mathrm{He}$ & $0.90 \pm 0.20$ & 1 & 1 & 14.4
\end{tabular}

lengths, obtaining values of $0.75 \pm 0.10$ and $0.47 \pm 0.06$ at 248 and $193 \mathrm{~nm}$, respectively.

Using stable end product analysis, Johnston et al. ${ }^{38}$ concluded that the quantum yield of channel 15 is unity over the wavelength range $200-300 \mathrm{~nm}$. Also, in a direct quantum yield determination, Jolly et al. ${ }^{39}$ measured $\phi_{\mathrm{HNO}_{3}}^{\mathrm{OH}}=0.89 \pm 0.08$. Taken together, these investigations indicate that the lowest energy photodissociation pathway, channel 15 , is the dominant pathway at $248 \mathrm{~nm}$ and channel 16 becomes important possibly at $222 \mathrm{~nm}$ and certainly by $193 \mathrm{~nm}$. Except for the results of Schiffman et al., ${ }^{41}$ these studies also suggest $\phi_{\mathrm{HNO}_{3}}^{\mathrm{OH}}(248 \mathrm{~nm})$ $=1$. Since at $248 \mathrm{~nm}$ there is insufficient energy for the $\mathrm{NO}_{2}$ from channel 15 to dissociate and channel 15 is the only energetically available route to give rise to $\mathrm{OH}$, the quantum yield of $\mathrm{OH}$ from $\mathrm{HNO}_{3}$ at $248 \mathrm{~nm}, \phi_{\mathrm{HNO}}^{\mathrm{OH}}(248 \mathrm{~nm})$, is equivalent to $\phi_{\mathrm{HNO}_{3}}^{\mathrm{NO}_{2}}(248 \mathrm{~nm})$.

In the analysis of the present data we assume, on the basis of the majority of the literature results, a unity quantum yield for channel 15 at $248 \mathrm{~nm}$. The retrieved quantum yield from PAN is, therefore, an upper limit to the actual value. Future refinements in the $\mathrm{HNO}_{3}$ quantum yield values will require appropriate scaling of the PAN results. The summary of data obtained over a range of total pressures, carrier gases, and concentrations of PAN is shown in Table 1. A variance weighted average of the relative product yields listed in Table 1 is $0.83 \pm 0.08$, where the quoted uncertainty is two standard deviations in data precision. When the uncertainties in the ratio of the PAN optical cross sections at the absorption and photolysis wavelengths are incorporated into the result the error increases slightly to \pm 0.09 .

\section{Discussion}

In the analysis of our data we have assumed a unity quantum yield for production of $\mathrm{NO}_{2}$ from $\mathrm{HNO}_{3}$ photolysis at $248 \mathrm{~nm}$. This assumption is supported by results of several previous investigations. However, recent results of Schiffman et al. ${ }^{4 !}$ point to a significantly lower quantum yield. Employment of these latter results would substantially lower our calculated $\phi_{\mathrm{PAN}}^{\mathrm{NO}_{2}}(248 \mathrm{~nm})$ to a value of $0.62 \pm 0.11$. As an internal test, we conducted a few photolysis experiments with $\mathrm{ClONO}_{2}$ over the pressure range from 1 to 8 Torr in $\mathrm{Ar}$ and compared the signal strengths with $\mathrm{HNO}_{3}$ photolysis data taken under the same conditions. Referencing the relative signals to the recently published literature value of $\phi_{\mathrm{ClONO}_{2}}^{\mathrm{NO}_{2}}(248 \mathrm{~nm})^{42}$ leads to better consistency if $\phi_{\mathrm{HNO}}^{\mathrm{NO}_{2}}(248 \mathrm{~nm})$ is assumed to be unity rather than 0.75 , as reported by Schiffmann et al. Consequently, these conclusions support the results of Turnipseed $e t$ al. ${ }^{37}$ and others ${ }^{38.39}$ which imply a unit quantum yield of $\mathrm{NO}_{2}$ from $\mathrm{HNO}_{3}$ photolysis at $248 \mathrm{~nm}$. However, the $\mathrm{ClONO}_{2}$ photochemical system is complex and further quantitative measurements of $\mathrm{HNO}_{3}$ photolysis products are warranted in order to resolve this discrepancy.

The analysis of the present data suggests that $\mathrm{NO}_{2}$ is the major nitrogen-containing product from PAN photolysis at $248 \mathrm{~nm}$; 
however, because of large experimental uncertainties we cannot preclude the possibility of other nitrogen-containing photoproducts, such as $\mathrm{NO}_{3}$ from a direct mechanism (channels $2 \mathrm{a}$ or $3 \mathrm{a}$ ) or NO formed from the secondary dissociation of intemally excited $\mathrm{NO}_{2}$ (channels $1 \mathrm{~b}$ ). The mechanism(s) for $\mathrm{NO}_{2}$ generation from $248 \mathrm{~nm}$ PAN photolysis can be direct (channels 1a or 4a) and/or indirect from secondary dissociation of $\mathrm{NO}_{3}$ (channels $2 b, 3 b$, or $3 c$ ). Although the present data cannot unambiguously resolve which of these channels give rise to the $\mathrm{NO}_{2}$, we consider channels la and $4 \mathrm{a}$, where one and two bonds are broken, respectively, to be the most likely photolysis pathways. Both $1 \mathrm{a}$ and $4 \mathrm{a}$ are expected to produce the same atmospheric effect, because the acetyl radical produced in 4 a will rapidly recombine with molecular oxygen to form peroxy acetyl radical which is the organic product of la. Moreover, the formation of $\mathrm{NO}_{2}$ as the nitrogen-containing photoproduct of these reaction channels represents a net chemical null cycle for PAN. Consequently, the major role of PAN in the stratosphere and upper troposphere is as a long range transport vehicle for $\mathrm{NO}_{2}$.

We consider other $\mathrm{NO}_{2}$ forming mechanisms to be unlikely. Production of $\mathrm{NO}_{2}$ from the secondary dissociation of the $\mathrm{NO}_{3}$ product from channels 2 and 3 requires that the $\mathrm{NO}_{3}$ be substantially internally excited. This requirement is not simultaneously compatible with our finding that the $\mathrm{NO}_{2}$ product from PAN photolysis at $248 \mathrm{~nm}$ contains a significant amount of internal energy. In order for the $\mathrm{NO}_{2}$ to be electronically excited, as is observed, it must have energy in excess of approximately $10000 \mathrm{~cm}^{-1}$.30 The lower limit of the total energy necessary to form electronically excited $\mathrm{NO}_{2}$ by channels $2 \mathrm{~b}$ and $3 \mathrm{~b}$ is $105 \mathrm{kcal} / \mathrm{mol}$ and $97.8 \mathrm{kcal} / \mathrm{mol}$, respectively. Since the energy of the $248 \mathrm{~nm}$ photon is $115.3 \mathrm{kcal} / \mathrm{mol}$, this leaves less than $20 \mathrm{kcal} / \mathrm{mol}$ of energy available for internal excitation of the other photoproducts and for product translational energy. An investigation of the photolysis of methyl nitrate at $248 \mathrm{~nm}$, a molecule similar to PAN, has shown that an average of 23 $\mathrm{kcal} / \mathrm{mol}$ is deposited into product translational energy and between 47 to $72 \mathrm{kcal} / \mathrm{mol}$ of energy is in the internal energy of the photoproducts. ${ }^{43}$ Similar energy disposal was observed in the photolysis of chlorine nitrate, another closely related molecule. ${ }^{42}$ On the basis of these results we conclude on energetic grounds that the $\mathrm{NO}_{2}$ is being produced directly from either channel la or $4 \mathrm{a}$ and $\mathrm{NO}_{2}$ production from secondary dissociation of $\mathrm{NO}_{3}$ is highly unlikely.

Acknowledgment. The research described in this paper was carried out at the Jet Propulsion Laboratory, California Institute of Technology, under contract with the National Aeronautics and Space Administration.

\section{References and Notes}

(1) Kleindienst, T. E. Res. Chem. Intermed. 1994, 20, 335 and references within.

(2) Aikin, A. C.: Herman, J. R.: Maier, E. J. R.; McQuillan, C. J. Planet. Space Sci. 1983, 3I, 1075.

(3) Singh, H. B.; Salas, L. J.: Viezee, W. Nature 1986, 321, 588.

(4) Kasting J. F.; Singh, H. B. J. Geophys. Res. 1986, 91.13239.

(5) Shepson. P. B.: Hastie, D. R.; So, K. W.: Schiff. H. I. Atmos. Environ. 1992, 26A, 1259.
(6) Derwent, R. G.: Jenkin. M. E. Atmos. Environ. 1991, 25A, 1661. (7) Kasibhatla, P. S.; Levy, H., П; Moxim, W. J. J. Geophys. Res. 1993. 98,7165 .

(8) Honrath, R. E.; Jaffe, D. A. J. Geophys. Res. 1992, 97, 20615.

(9) Singh, H. B.; O'Hara, D.; Herlth, D.; Bradshaw, J. D.; Sandholm, S. T.; Gregory, G. L.; Sachse, G. W.; Blake, D. R.; Crutzen, P. J.; Kanakidou, M. A. J. Geophys. Res. 1992, 97, 16511.

(10) Parrish, D. D.; Hahn, C. J.; Williams, E. J.: Norton, R. B.; Fehsenfeld, F. C.: Singh. H. B.: Shetter, J. D.: Gandrud, B. W.: Ridley, B. A. J. Geophys. Res. 1992, 97, 15883 .

(11) Orlando, J. J.; Tyndall, G. S.; Calvert. J. G.; Atmos. Environ. 1992. $26 A, 3089$.

(12) Roberts, J. M.; Bertman, S. B. Int. J. Chem. Kinetics 1992. 24. 297.

(13) Grosjean, D: Grosjean, E.; Williams, E. L., II. J. Air Waste Manage. Assoc. 1994, 44, 391.

(14) Wallington. T. J.: Atkinson. R.; Winer, A. M. Geophys. Res. Lett. $1984,1,861$.

(15) Tsalkani, N.; Mellouki, A.; Poulet, G.; Toupance, G.; Le Bras, G J. Atmos. Chem. 1988, 7, 409 .

(16) Wallington. T. J.; Andino, J. M.; Ball, J. C.; Japar, S. M. J. Atmos. Chem. 1990, 10, 301

(17) Talukdar, R. K.; Burkholder, J. B.; Schmoltner, A.-M.; Roberts. J M.; Wilson, R.; Ravishankara, A. R. Manuscript in preparation.

(18) Holdren, M. W.: Spicer, C. W.; Hales, J. M. Atmos. Environ. 1984 $I 8,1171$.

(19) Moore, S. B.; Friedl, R. R.; Sander, S. P. Manuscript in preparation.

(20) Langer. S.; Wängberg. I.; Ljungström. E. Atmos. Environ. 1992 $26 A, 3089$.

(21) Senum, G. I.; Lee, Y.-N.; Gaffney. J. S. J. Phys. Chem. 1984, 88, 1269.

(22) Libuda. H. G.: Zabel. F. Paper presented at 21 st Informal Conference on Photochemistry, Toronto, May, 1994.

(23) Sicilia, E.; Di Maio, F. P.: Russo, N. J. Phys. Chem. 1993, 97, 528

(24) Bridier. I.: Caralp. F.; Loirat, H.; Lesclaux, B. V.; Veyret, B.; Becker, K. H.: Reimer, A.; Zabel, F. J. Phys. Chem. 1991, 95, 3594.

(25) Hoimes, J. L.: Lossing. F. P.; Mayer, P. M. J. Am. Chem. Soc. 1991, 113, 9723

(26) Hendry, D. G.; Kenley, R. A. J. Am. Chem. Soc. 1977, 99, 3198.

(27) DeMore. W. B.; Sander. S. P.; Golden. D. M.; Hampson, R. F.; Kurylo. M. J.: Howard. C. J.: Ravishankara, A. R.; Kolb, C. E.; Molina, M. J. JPL Publ. 92-201992.

(28) Gaffney. J. S.: Fajer, R.; Senum, G. I. Atmos. Environ. 1984, 18 , 215.

(29) Bruckmann. P. W.; Willner, H. Environ. Sci. Technol 1983, I7, 352.

(30) Okabe. H. Photochemistry of Small Molecules; John Wiley and Sons: New York, 1978

(31) Marrero. T. R.: Mason, E. A. J. Phys. Chem. Ref. Data 1972, I. 3. (32) Mazely. T. L.; Friedl, R. R.; Sander, S. P. J. Chem. Phys. 1994. 100,8040 .

(33) Johnston, H. S.: Graham, R. J. Phys. Chem. 1973, 77, 62.

(34) Biaume, F. J. Photochem 1973, 2, 139

(35) Molina. L. T.: Molina. M. J. J. Photochem. 1981, 15, 97

(36) Margitan, J. J.; Watson, R. T. J. Phys. Chem. 1982, 86, 3819.

(37) Turnipseed. A. A.; Vaghjiani, G. L.; Thompson, J. E.; Ravishankara A. R. J. Chem. Phys. 1992, 96, 5887

(38) Johnston. H. S.: Chang, S.-G.; Whitten, G. J. Phys. Chem 1974. $78,1$.

(39) Jolly, G. S.; Singleton, D. L.; McKenney, D. J.; Paraskevopoulos. G. J. Chem. Phys. 1986, 84, 6662 .

(40) Kenner. R. D.; Rohrer, F.; Papenbrock, Th.; Stuhl F., J. Phys. Chem. $1986,90,1294$.

(41) Schiffman, A: Nelson, D. D., Jr.; Nesbitt, D. J. J. Chem. Phys. $1993,98,6935$.

(42) Minton, T. K.; Nelson, C. M.; Moore, T. A.; Okumura, M. Science $1992,258,1342$

(43) Yang, X.; Felder, P.; Huber, J. R. J. Phys. Chem. 1993, 97, 10903.

JP942953N 